\title{
Thrips on fabaceous plants and weeds in an ecotone in northeastern Brazil
}

\author{
Tripes em plantas fabáceas e ervas daninhas em um ecótono no nordeste do Brasil
}

\author{
Élison Fabrício Bezerra Lima ${ }^{I^{*}}$ Roberto Antonio Zucchi
}

ABSTRACT

Thrips (Thysanoptera) on 33 species of Fabaceae (ornamental and forage) and some weed species were surveyed in areas of caatinga-cerrado ecotone in northeastern Brazil. Twenty species of thrips were identified, all of which are associated for the first time with the plants sampled in this study, totaling 26 new host associations, based on collections of immatures. Five species are probably new to science, illustrating the diversity of thrips in the region. A few thrips species that also occur as pests in other regions of Brazil are discussed. Our data extend the distribution area of thrips species and provide basic information on their associated plants.

Key words: pests, host association, identification, Thysanoptera.

\section{RESUMO}

Tripes (Thysanoptera) em 33 espécies de Fabaceae (ornamentais e forrageiras) e algumas espécies de ervas daninhas foram inventariadas em áreas de ecótono caatinga-cerrado no nordeste do Brasil. Vinte espécies de tripes foram identificadas, das quais todas são associadas pela primeira vez com as plantas amostradas neste estudo, totalizando 26 novas associações hospedeiras, baseadas em coletas de imaturos. Cinco espécies são provavelmente novas para a ciência, ilustrando a diversidade de tripes na região. Poucas espécies de tripes que também ocorrem como pragas em outras regiões do Brasil são discutidas. Nossos dados estendem a área de distribuição dessas espécies de tripes e disponibilizam informações básicas sobre suas plantas associadas.

\author{
Palavras-chave: pragas, associação hospedeira, \\ identificação, Thysanoptera.
}

\section{INTRODUCTION}

Thrips (Thysanoptera) are pests of many cultivated plants in Brazil, and at least one forage crop and 13 ornamentals are attacked by these insects. Damage from thrips ranges from minor qualitative injuries to loss of leaf pigmentation and appearance of dark spots, leading to decreases in yield (MONTEIRO et al. 1999; AFONSO, 2008). Thrips can shelter in weeds and then disperse to crop land where they become a problem (LIMA et al., 2000a,b).

In spite of their agricultural importance, few studies focusing on the fauna of Thysanoptera in agroecosystems had been conducted in northern Brazil, and records of these pests are concentrated in the Southern and Southeastern regions (MONTEIRO, 2002; MONTEIRO \& LIMA, 2011). Groups inadequately sampled, such as Thysanoptera, need to be more intensively studied in areas where they are neglected. In the states of Piauí and Maranhão, which have typical ecotone

\footnotetext{
'Departamento de Entomologia e Acarologia, Escola Superior de Agricultura "Luiz de Queiroz" (ESALQ), Universidade de São Paulo (USP), 13418-900, Av. Pádua Dias, 11, Piracicaba, SP, Brasil. E-mail: elisonfabricio@hotmail.com. *Corresponding author. Received 04.28.15 Approved 08.03.15 Returned by the author 10.23.15 CR-2015-0613.R1
} 
vegetation (caatinga-cerrado), no thrips species were recorded yet on forage, ornamental or weed plants.

Fabaceae species are commonly grown in arid regions of Brazil due to their ease cultivation, abundance and productivity (MCKEY, 1994; MOURÃO et al., 2011). However, in spite of these characteristics and although a highly diverse assemblage of thrips may be associated with Fabaceae in Brazil (MONTEIRO, 2002), little is known regarding thrips and these plant species in caatinga-cerrado ecotone vegetation in northeastern Brazil.

This study surveyed the thrips species associated with widely used ornamental and forage plants (Fabaceae), as well as some weed species, in caatingacerrado ecotone areas in this region. Data on host associations were provided for some species. This basic information is important for the development integrated pest management strategies, increasing the knowledge of thrips in this region.

\section{MATERIAL AND METHODS}

Thrips were collected from 33 species of plants (ornamental and forage fabaceous species, along with nearby weeds), 30 of which are native (Tables 1, 2, 3 and 4). The surveys were conducted in two municipalities with typical caatinga-cerrado ecotone vegetation, São Luís $\left(02^{\circ} 35^{\prime} 01^{\prime \prime} \mathrm{S} ; 44^{\circ} 12^{\prime} 33^{\prime \prime} \mathrm{W}\right)$ and Teresina $\left(05^{\circ} 05^{\prime} 21^{\prime \prime} \mathrm{S} ; 42^{\circ} 48^{\prime} 07^{\prime \prime} \mathrm{W}\right)$, in 2010 (July, August and December) and 2011 (January and July), the period of planting and flowering of fabaceous plants in the region.
Flowers and leaves were taken to the laboratory for thrips screening, which were preserved in AGA and mounted on glass slides (MOUND \& MARULLO, 1996) for identification. Host associations were established based on immatures, which were identified using the compendia of SPEYER \& PARR (1941), VANCE (1974), HEMING (1991) and VIERBERGEN et al. (2010). When identification was not possible, host associations were based on larvae associated with adults present (PINENT et al., 2005). Voucher specimens are deposited in the Thysanoptera collection of the Department of Entomology and Acarology (ESALQ/USP). Comparisons between thrips of the ecotone and from other Brazilian regions are provided, especially with the more southern states, in which distribution data are more abundant.

\section{RESULTS AND DISCUSSION}

Twenty thrips species were collected on 28 of the 33 plant species sampled (nine botanical families) in the states of Maranhão (Tables 1 and 3) and Piauí (Tables 2 and 4). Twenty-six host associations established between ten thrips species and ten forage, ornamental and weed species were recorded for the first time in Brazil. Species from five genera, namely Aulacothrips (the only ectoparasitic genus in Thysanoptera), Frankliniella, Haplothrips, Hydatothrips (Figure 1A), and Scirtothrips (Figure 1B) were not identified, and are probably new to science (Tables 2, 3 and 4). Our data add new information for the Thysanoptera fauna in the Brazilian caatingacerrado ecotone, which shows a considerable

Table 1 - Thrips species found on ornamental and forage plants (Fabaceae) in the cerrado-caatinga ecotone in São Luís, Maranhão, Northeastern Brazil.

\begin{tabular}{|c|c|}
\hline Plant species & Thrips species \\
\hline Acacia sp. $^{\mathrm{O}, \mathrm{E}}$ & Frankliniella brevicaulis ${ }^{*+}, \boldsymbol{F}$. insularis $^{*+}$ \\
\hline Arachis pintoi $^{\mathrm{F}, \mathrm{N}}$ & F. schultzei $i^{*^{+}}$ \\
\hline Caesalpinia pulcherrima ${ }^{\mathrm{O}, \mathrm{N}}$ & F. schultzei ${ }^{*^{+}}$ \\
\hline
\end{tabular}

${ }^{*}$ Host association based on larvae collection; +New record of association with plant; ${ }^{\mathrm{F}}$ Forage; ${ }^{\mathrm{O}}$ Ornamental; ${ }^{\mathrm{N}} \mathrm{Native} ;{ }^{\mathrm{E}}$ Exotic. 
Table 2 - Thrips species found on ornamental and forage plants (Fabaceae) in the cerrado-caatinga ecotone in Teresina, Piauí, Northeastern Brazil.

\begin{tabular}{|c|c|}
\hline Plant species & Thrips species \\
\hline Acacia mangium $^{\mathrm{O}, \mathrm{E}}$ & - \\
\hline Bauhinia forficata ${ }^{\mathrm{O}, \mathrm{N}}$ & Frankliniella brevicaulis $^{{ }^{+}}, F$. gardeniae ${ }^{+}, F$. insularis $^{+}, F$. tritici $^{+}$ \\
\hline Canavalia brasiliensis ${ }^{\mathrm{F}, \mathrm{N}}$ & F. gardeniae $^{+}, F$. insularis ${ }^{*+}$, Salpingothrips minimus ${ }^{+}$, Hydatothrips sp. $^{{ }^{*}}$ \\
\hline Chamaecrista rotundifolia $\mathrm{a}^{\mathrm{F}, \mathrm{N}}$ & - \\
\hline Clitoria fairchildiana $a^{\mathrm{O} N \mathrm{~N}}$ & Heliothrips Haemorrhoidalis $^{{ }^{+}},{\text {Haplothrips gowdey } i^{+}}^{+}$ \\
\hline Cratylia argentea ${ }^{\mathrm{F}, \mathrm{N}}$ & F. gardeniae $^{+}, F$. insularis ${ }^{*+}, F$. schultzei ${ }^{+}, F$. tritici ${ }^{+}$ \\
\hline Leucaena leucocephala ${ }^{\mathrm{F}, \mathrm{E}}$ & F. brevicaulis ${ }^{*+}, F$.gardeniae ${ }^{+}, F$.gemina ${ }^{+}, F$. schultzei ${ }^{+}$ \\
\hline Mimosa caesalpiniifolia ${ }^{\mathrm{F}, \mathrm{N}}$ & $F$. gardeniae $^{+}, F$. gemina $^{+}, F$. schultzei $^{+}, F$. tritici $^{+}$ \\
\hline Mimosa verrucosa $a^{\mathrm{O}, \mathrm{N}}$ & $F$. gardeniae $^{+}, F$.gemina ${ }^{+}, F$. tritici $^{+}$ \\
\hline Mucuna pruriens ${ }^{\mathrm{F}, \mathrm{N}}$ & - \\
\hline Pityrocarpa moniliformis ${ }^{\mathrm{F}, \mathrm{N}}$ & F. gardeniae ${ }^{+}, \mathrm{F}$. gemina ${ }^{+}, \mathrm{Ha}$. gowdeyi ${ }^{+}$, Frankliniella $\mathrm{sp}$. \\
\hline Poincianella gardneriana ${ }^{\mathrm{O}, \mathrm{N}}$ & Aulacothrips sp. ${ }^{+}, F$. insularis ${ }^{*+}, F$. tritici $^{+}$, He haemorrhoidalis ${ }^{*+}$, Selenothrips rubrocinctus ${ }^{+}$ \\
\hline Senna alata $^{\mathrm{O}, \mathrm{N}}$ & F. brevicaulis ${ }^{*+}, F$. insularis ${ }^{+}, F$. schultzei ${ }^{+}, F$. tritici $^{+}$ \\
\hline Stylosanthes humilis ${ }^{\mathrm{F}, \mathrm{N}}$ & - \\
\hline
\end{tabular}

"Host association based on larvae collection; + New record of association with plant;

${ }^{\mathrm{F}}$ Forage; ${ }^{\mathrm{O}}$ Ornamental; ${ }^{\mathrm{N}}$ Native; ${ }^{\mathrm{E}}$ Exotic.

species richness. Except for Aulacothrips sp. (Heterothripidae) and Haplothrips gowdeyi (Phlaeothripidae), all of the thrips species belong to the family Thripidae.

Some of the species collected are previously known and are pests of many crops in Brazil (MONTEIRO et al., 1999). Although thrips occur in large populations on ornamental and forage plants, we observed only minor damage such as markings on the floral tissue (Figure 1C). On ornamental plants, these injuries can reduce the commercial value, but they are not common in the field, and are not important enough to cause significant qualitative losses. However, the populations of some thrips species that are pests on other crops can increase depending on climate factors, and occasionally develop into serious problems. The pest thrips, Frankliniella schultzei (Figure 1D), F. brevicaulis, $\boldsymbol{F}$. insularis, Heliothrips haemorrhoidalis and Selenothrips rubrocinctus were collected on forage and ornamental plants. However, only F. schultzei and H. haemorrhoidalis are known to damage ornamentals in Brazil (MONTEIRO et al., 1999; LIMA et al., 2012).

Several new associations between thrips and weed species were established from these collections (Tables 3 and 4); however, only few observations related to thrips species on these plants in the caatinga-cerrado ecotone

Table 3 - Thrips species found on native species of weeds in the cerrado-caatinga ecotone in São Luís, Maranhão, Northeastern Brazil.

\begin{tabular}{|c|c|}
\hline Plant species & Thrips species \\
\hline Aeschynomene sp. ${ }^{1}$ & Neohydatothrips paraensis ${ }^{+}$ \\
\hline Centrosema brasilianum $^{1}$ & Frankliniella schultzei ${ }^{*+}$ \\
\hline Ipomoea asarifolia $^{2}$ & Dendrothripoides innoxius $^{*+}$, Scirtothrips sp. ${ }^{*}$ \\
\hline
\end{tabular}

${ }^{*}$ Host association based on larvae collection; + New record of association with plant species; ${ }^{1}$ Fabaceae $;{ }^{2}$ Convolculaceae. 
Table 4 - Thrips species found on native species of weeds in the cerrado-caatinga ecotone in Teresina, Piauí, Northeastern Brazil.

\begin{tabular}{|c|c|}
\hline Plant species & Thrips species \\
\hline Althernanthera sp. ${ }^{1}$ & Haplothrips sp. ${ }^{*}$ \\
\hline Calopogonium mucunoides $^{2}$ & Frankliniella insularis,+ Salpingothrips minimus + \\
\hline Centrosema brasilianum $^{2}$ & F. schultzei ${ }^{*}+$, F. insularis $^{+}$, H. gowdeyi + \\
\hline Centratherum sp. ${ }^{3}$ & H. gowdeyi ${ }^{*}$ \\
\hline Cleome sp. $^{4}$ & F. schultzei, F. tritici \\
\hline Commelina sp. $^{5}$ & Chaetanaphothrips orchidii \\
\hline Desmodium sp. ${ }^{2}$ & F. schultzei \\
\hline Dioclea lasiophylla ${ }^{2}$ & $F_{\text {gardeniae }}+$, F. insularis $^{*}+, F$. schultze $^{+}, F_{\text {tritici }}{ }^{*}+$ \\
\hline Macroptilium lathyroides $^{2}$ & Bradinothrips musae,+ F. schultzei,+ F. tritici ${ }^{+}$, Caliothrips phaseoli ${ }^{*}+$ \\
\hline Richardia sp. $^{6}$ & Hoodothrips lineatus, F. schultzei, C. phaseoli, H. gowdeyi ${ }^{*}$ \\
\hline Senna obtusifolia ${ }^{2}$ & Frankliniella sp., Scirtothrips sp. ${ }^{*}$ \\
\hline Sida sp. $^{7}$ & H. gowdeyi ${ }^{*}$ \\
\hline Turnera sp. $^{8}$ & - \\
\hline Zornia sp. $^{2}$ & - \\
\hline
\end{tabular}

"Host association based on larvae collection; + New record of association with plant species; ${ }^{1}$ Amaranthaceae $;{ }^{2}$ Fabaceae $;{ }^{3}$ Asteraceae; ${ }^{4}$ Cleomaceae $;{ }^{5}$ Commelinaceae $;{ }^{6}$ Rubiaceae $;{ }^{7}$ Malvaceae $;{ }^{8}$ Turneraceae.

are discussed relatively to their occurrence and associations in other Brazilian regions. As no immatures of $\boldsymbol{F}$. schultzei were found on Desmodium sp., the host association was not be determined, although this thrips had been recorded on Desmodium tortuosum and Senna obtusifolia elsewhere in Brazil (LIMA et al. 2000A). The association between $\boldsymbol{F}$. insularis and Dioclea lasiophylla is new; however, this species was associated with Dioclea violacea in the state of Rio Grande do Sul (PINENT et al., 2005).

Other pest thrips collected on weeds were Caliothrips phaseoli (Figure 1E), Bradinothrips musae (Figure 1F), Chaetanaphothrips orchidii and Hoodothrips lineatus. Although these species are pests of many crops in Brazil, none is known to damage forage plants or ornamentals (MONTEIRO et al., 1999).

The host associations between $\boldsymbol{F}$. schultzei, $\boldsymbol{C}$. phaseoli and weeds (Tables 3 and 4) are important in order to establish cultural practices to reduce or prevent invasions of thrips populations that are harbored in these weeds into crop and/or adjacent areas. Knowledge of the weed species on which thrips develop helps in the management of a pest thrips by removing the weed or by using it as trap plants (LIMA et al., 2000a,b).

Ipomoea asarifolia showed high infestation by Dendrothripoides innoxius, mostly at the base and inside closed leaves (Figures 1 G, 1H and 1I). Although Ipomoea spp. are known as hosts of D. innoxius, this is the first record on I. asarifolia in Brazil. The leaves appear wrinkled due to D. innoxius feeding on the plant tissue (Figure 1G). This weed is toxic to cattle (MEDEIROS et al., 2003; TORTELLI et al., 2008), which can die if they consume a large amount of the plant. D. innoxius could be a possible candidate for biocontrol of this weed.

\section{CONCLUSION}

Twenty thrips species occur on 28 forage, ornamental (Fabaceae) and surrounding weeds in the ecotone cerrado-caatinga in Northeastern the Country, of which five are probably new to science. Twenty-six host associations are established for the first time in Brazil. These data, along with the possibility of weed control by $D$. innoxius, can be used as cultural practices to control pest thrips and increases the knowledge of thrips diversity in Brazil. 

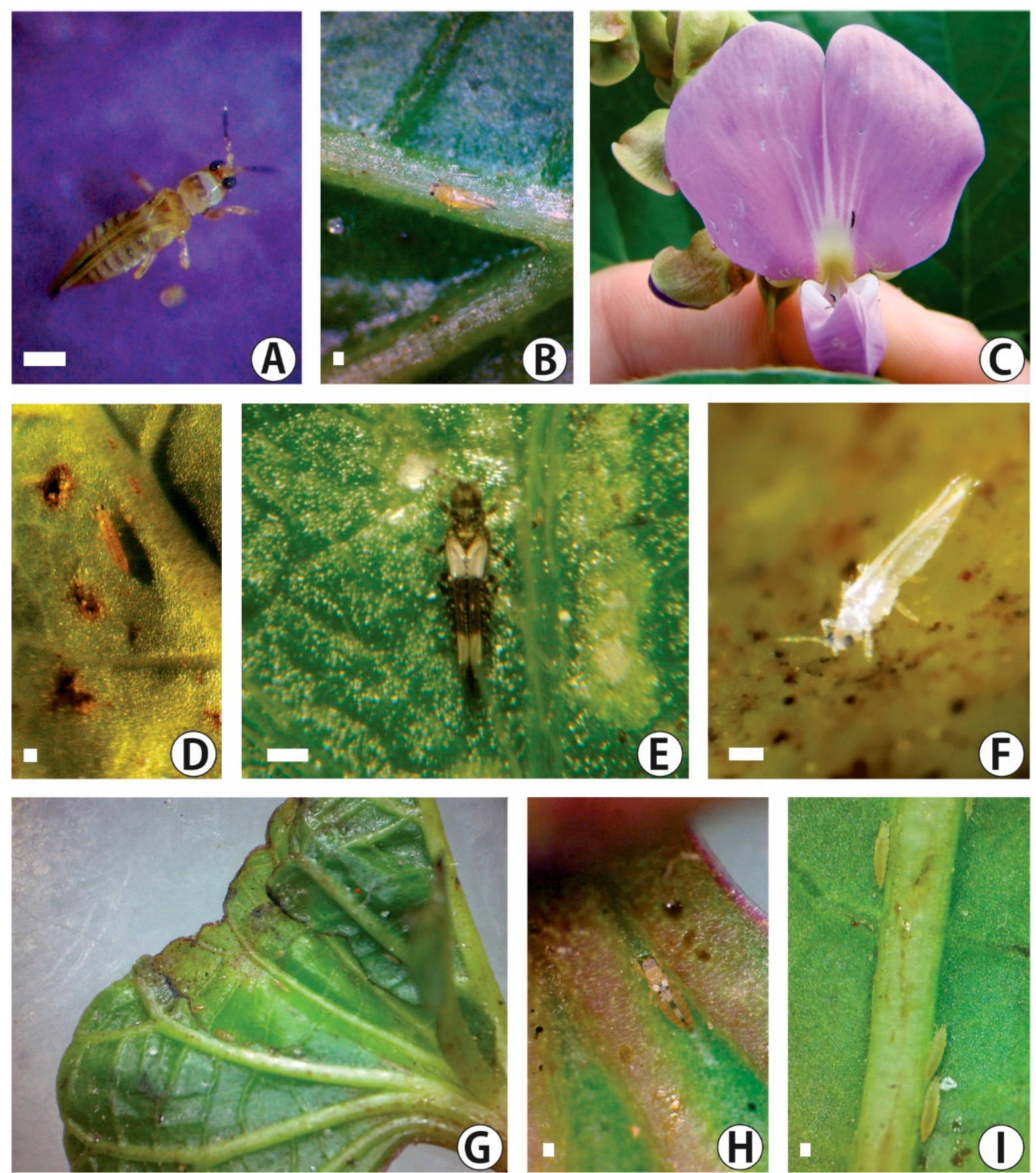

Figure 1 - Species of thrips from the northeastern Brazil ecotone. (A) Hydatothrips sp. (B) Scirtothrips sp. (C) Injuries caused by Frankliniella insularis to leaves of Canavalia brasiliensis. (D) Frankliniella schultzei. (E) Caliothrips phaseoli. (F) Bradinothrips musae. (G) damage caused by Dendrothripoides innoxius to leaves of Ipomoea asarifolia. (H) Adult of D. innoxius. (I) Larvae of $\boldsymbol{D}$. innoxius. (Scale bars: $200 \mu \mathrm{m}$ ).

\section{ACKNOWLEDGMENTS}

To Prof. Dr. Lúcia da S. Fontes, Dr. Ranyse B. Querino and José Campelo, who kindly provided support during field research in Piaui; to Prof. Dr. Rosângela Malheiros, Prof. Dr. Maria José Corrêa and Wendell Dias, who equally kindly provided support during field research in Maranhão. MSc Wanessa Scopel for providing the photo of Caliothrips phaseoli. To CAPES (Coordenação de Aperfeiçoamento de Pessoal de Nível Superior, Ministry of Education), for the master's scholarship to the first author. 


\section{REFERENCES}

AFONSO, A.P.S. Insetos pragas da alfafa. In: MITTELMANN, A. et al. Tecnologias para a produção de alfafa no Rio Grande do Sul. Pelotas: Embrapa Clima Temperado, 2008. Cap. 2, p.17-32.

HEMING, B.S. Order Thysanoptera. In: STEHR, FW. Immature insects. Dubuque: Kendall/Hunt, 1991. Cap.28, p.1-21. 2v.

LIMA, M.G.A. et al. Ocurrence of Frankliniella schultzei (Trybom) (Thysanoptera: Thripidae) at weed species. Planta Daninha, v.18, n.2, p.367-372, Aug. 2000a. Available from: $<$ http://www.scielo.br/ scielo.php?pid=S0100-83582000000200017\&script $=$ sci_arttext $>$. Accessed: Apr. 24, 2015. doi: 10.1590/S0100-83582000000200017.

LIMA, M.G.A. et al. Host plants for Enneothrips flavens (Moulton, 1941) during the inter peanut growing season. Revista de Agricultura, v.75, p.129-134, Jun. 2000b.

LIMA, E.F.B. et al. Heliothrips haemorrhoidalis (Bouché, 1833) (Thysanoptera: Thripidae) danificando samambaia-de-metro (Polypodium persicifolium Desv.) (Polypodiales: Polypodiaceae) no Brasil. Revista de Agricultura, v.87, n.2, p.119-121, Jun. 2012.

MCKEY, D. Legumes and nitrogen: the evolutionary ecology of a nitrogen-demanding lifestyle. In: SPRENT, J.I.; MCKEY, D. (Eds.). Advances in legume systematics. The Nitrogen Factor. Kew: Royal Botanic Gardens, 1994. Cap.5, p.211-228.

MEDEIROS, R.M.T. et al. Tremorgenic syndrome in goats caused by Ipomoea asarifolia in Northeastern Brazil. Toxicon, v.41, n.7, p.933-935, Jun. 2003.Available from: <http://www.sciencedirect. com/science/article/pii/S0041010103000448>. Accessed: Apr. 24, 2015. doi: 10.1016/S0041-0101(03)00044-8.

MONTEIRO, R.C.; LIMA, E.F.B. Thysanoptera of Brazil. 2011. Available from: <http://www.lea.esalq.usp.br/thysanoptera/>. Online. Accessed: Feb. 10, 2015.

MONTEIRO, R.C. The Thysanoptera fauna of Brazil. In: INTERNATIONAL SYMPOSIUM ON THYSANOPTERA, 10.,
2001, Reggio Calabria, Italy. Proceedings... Canberra: Australian National Insect Collection, 2002. 390p. p.325-340.

MONTEIRO, R.C. et al. Thrips (Thysanoptera) as pests of plant production in Brazil. Revista Brasileira de Entomologia, v.43, n.3/4, p.163-171, Dec. 1999.

MOUND, L.A.; MARULLO, R. The Thrips of Central and South America: an introduction (Insecta: Thysanoptera). Memoirs on Entomology International, v.6, p.1-488, Jan. 1996.

MOURÃO, S.A. et al. Uso de leguminosas no Semiárido Mineiro. Sete Lagoas: Embrapa Sorgo e Milho, 2011. 91p.

PINENT, S.M.J. et al. Thysanoptera: plantas visitadas e hospedeiras no Parque Estadual de Itapuã, Viamão, RS, Brasil. Iheringia Série Zoologia, v.95, n.1, p.9-16, Mar. 2005.Available from: <http:// www.scielo.br/scielo.php?script $=$ sci arttext\&pid $=\mathrm{s} 0073-47212005000100002>$. Accessed: Apr. 24, 2015. doi: 10.1590/S0073-47212005000100002.

SPEYER, E.R.; PARR, W.J.The external structure of some Thysanopterous larvae. Transactions of the Royal Entomological Society of London, v.91, n.11, p.559-635, Jun. 1941.

TORTELLI, F.P. et al. Intoxicação por Ipomoea asarifolia em ovinos e bovinos na Ilha de Marajó. Pesquisa Veterinária Brasileira, v.28, n.12, p.622-626, Dec. 2008.Available from: $<$ http://www.scielo.br/scielo.php?pid=S $0100-$ 736X2008001200011\&script $=$ sci_arttext $>$. Accessed: Apr. 24, 2015. doi: 10.1590/S0100-736X2008001200011.

VANCE, T.C. Larvae of the Sericothripini (Thysanoptera: Thripidae), with reference to other larvae of the Terebrantia, of Illinois. Illinois Natural History Survey Bulletin, v.31, p.145208, Aug. 1974.

VIERBERGEN, G. et al. A key to the second instar larvae of the Thripidae of the Western Palearctic region (Thysanoptera). Tijdschrift voor Entomologie, v.153, p.99-160, Jun. 2010. 